Article

\title{
Family Environment Factors: Alcohol and Drug Misuse among Indonesian Students: Indonesia National Narcotics Survey of Students
}

\author{
Nohan Arum Romadlona ${ }^{1, *}$, Budi Utomo ${ }^{1}$ and Purwa Kurnia Sucahya ${ }^{2,}$, Monalisa ${ }^{2}$ \\ 1 Knowledge Hub for Reproductive Health, Universitas Indonesia; arumnohan@gmail.com; \\ budi.utomo.ui@gmail.com \\ 2 Center of Health Research, Universitas Indonesia; purwa.sucahya@gmail.com; mona.lisa@ui.ac.id \\ * Correspondence: arumnohan@gmail.com
}

\begin{abstract}
Family environment has an important role in determining the personality and behavior of a child. This study examined the impact of family environment on alcohol and drug misuse among Indonesian students. Data were obtained from National Illicit Drug Use surveys of students in Indonesia 2016, conducted in 18 provinces. Subjects were 35,340 students from 1,284 schools and universities with age range is 12-25 years. The surveys used the self-administered ModifiedUNODC Structured Illicit Drug questionnaire. Results show $13.7 \%$ students ever drink alcohol, and drug misuse were accounted for $2.1 \%$ students within the past year. Among students who drink alcohol, $11 \%$ also drug users. In the latter group, they were likely to receive verbal and physical violence from their parents and never discuss any problems with their parents. Individual living in a family with existing risky behavior (alcohol drinking and/or drug misuse) is the strongest risk factor of alcohol drinking (aOR: 4.78; 4.27-5.37) and drug misuse (aOR: 2.32; 1.79-3.01). The result indicates that family environment affects these risky behaviors in a target population. Adjustment through parental support, control, and parenting style, particularly in initiating parent-child communication, may demonstrate positive roles in preventing alcohol drinking and drug use strategies in this target population.
\end{abstract}

Keywords: Alcohol drinking; Drug misuse; Family environment; Indonesian students

\section{Introduction}

Adolescence is a phase where individuals continue to grow into maturity and have full of curiosity to try new things. The 2010 Population Census results show that Indonesia's population is 237.6 million and $26.67 \%$ of them are adolescents age $15-24$ which certainly a demographic bonus that can affect social, economic, and national development aspects in the future if these people are healthy and productive [1]. Being a student and adolescent is a very vulnerable period, as this is a period of self-seeking and personality. Health problems that occur in adolescents are associated with risky behavior such as smoking, drinking alcohol, drug use, and having premarital sex [2].

Alcohol consumption leads to health problems and affects productivity. Young people are vulnerable to be engaged in alcohol drinking and susceptible to harmful effects due to this behavior. Hence, this issue gradually gains concern in public health [3]. Adolescents who drink alcohol exhibit a distinctive behavior that affects themselves and other people and their surroundings, including families, the environment, schools, peers, even conducting action against the law. Alcohol consumption gives an inverse association toward the academic performance of a student. Aggressive behavior, less motivation, lower attachment, and commitment in learning, followed by underperformance at school, are commonly observed in students who consume alcohol [4]. A survey in 2012 shows a 
higher number of Indonesian male adolescents (39.2\%) than 5.9\% of female adolescents who drank alcohol [5]. In some areas in Indonesia, drinking alcohol has become a culture as a form of celebration on certain occasion despite consuming alcohol is prohibited by religion [6]. Furthermore, people who ever tried to drink alcohol tend to initiate other risky behaviors such as drug abuse.

Drug addiction is one of the health problems that leads to death and disability and creates a socio-economic burden. Narcotics and psychotropic drugs are intended to be used for medicinal purposes. Uncontrolled use of these drugs can cause dependence as well as harmful effects to the users, including deteriorating physical function and mental alteration such as disturbance of perception, thinking, creation and emotions that eventually change a person's behavior. Globally, the increasing prevalence of drug abuse can be seen from the year 2006 to 2013 [7]. Moreover, in Indonesia, an incline percentage of drug users among adolescents can be seen, accounted for 24 to 28 percent [8,9]. This group is likely to yield a long-term impact as they may spend more time involved in drug abuse.

The family environment has an important role in determining the personality and behavior of a child. Several studies show that alcohol drinking and drug consumption may be influenced by family characteristics, schools, and peers or social groups[10-12]. Cases of divorced parents and child-unfriendly behavior (verbal expression, attitudes, and actions) could influence children's behavior in society. The quality of parent's marriage, level of family disagreement and conflict experienced by the child at home, coping mechanism, and parent-child discussions of behavior rules are seemingly important in forming child behavior. Marital conflict is associated with lower levels of parental monitoring of the children, poorer affection, and bonding [13]. This assumption was supported by some studies that demonstrate a link between family conflict and the presence of violence with a higher risk of alcohol drinking and drug use among school-age children $[14,15]$. Furthermore, when a child experiences violence and family conflict at an earlier age, it may interfere with the development of peer relationships in school, which unlikely to be positive [16].

Surveys related behaviors and sensitive issues is still quite taboo in Indonesia. Surveys are difficult and rarely conducted, and very high under reported. The output of several surveys that have been conducted in Indonesia mainly focused on finding the drugs prevalence, including describes the drug dealers and users in Indonesia. This study examines more deeply the association of family environment factors and student's behavior on alcohol drinking and drug abuse in Indonesia, as well as addressing potential aspects for future prevention program.

\section{Materials and Methods}

This study utilized a secondary data from the National Database of Illicit Drug Use surveys of students in 2016 in Indonesia conducted by the Indonesia National Narcotics Board (BNN) collaborated with the Centre for Health Research University of Indonesia. The survey covered 18 provinces, including 11 priority provinces by BNN based on several indicators such as the prevalence of drug abuse in general population, based on school level, and geographical area representation. The samples' distribution were 35,340 students from 1,284 schools of junior, senior high-school, and university that were randomly selected based on the criteria. Sample was represent the target The surveys used the self-administrated, modified UNODC structured illicit drug use questionnaire to collect data $[17,18]$. Data being collected included socio-demographic characteristics, illicit drug knowledge, sources of narcotics-related information, type of illicit drug used and frequency of use, access to illicit drug, smoking, and alcohol drinking. 


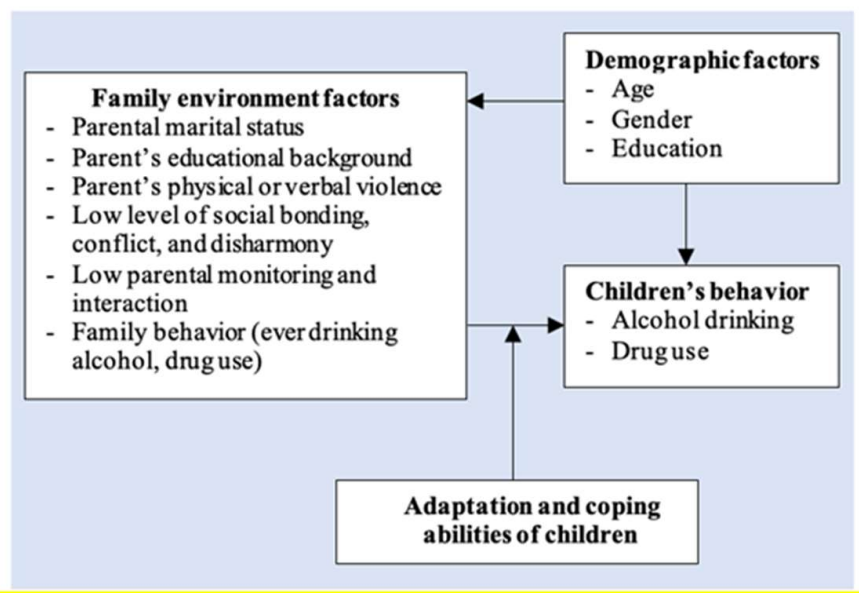

Figure 1. A modified-conceptual model on adaptation and coping abilities on young adult alcohol use and family environment by Karen M. Jannison 2016.

Two outcomes used in this analysis are alcohol drinking and drug use. Alcohol drinking and drug use are defined by the current prevalence (within past year use) and excluded students who responded 'do not know' or 'do not remember'. Selected respondents are students between 12 until 25 years old from students of junior, senior high-school, and university. Dependent variables, alcohol drinking and drug use, are categorical variables, and logistic regression maximum likelihood method is considered appropriate. The logit model appropriate when the issue of interest is to describe the odds of outcome. Odds are defined as the ratio of the probability of one outcome to another. The oods-ratio is supposed to have two groups of binary data with probabilities of success $\mathrm{p} 1$ and $\mathrm{p} 2$, such that logit(p1)= $\beta+\gamma$ and $\operatorname{logit}(\mathrm{p} 2)=\beta 0$, where $\beta 0$ and $\gamma$ are the parameters [19].

Family environmental factors are explained in a modified-conceptual model on adaptation and coping abilities on young adult alcohol use and the family environment by Karen M. Jennison 2016 [12]. Other mechanisms that describe risk factors for interpersonal violence experiences on alcohol consumption in adolescents can be seen in stress and coping theory developed by Lazarus and Folkman (1984). The hypothesis assumes that the student living in a family in which either or both parents had problems inside their family would be more likely to have risky behavior than the student lives in a conducive family. A Correlation matrix is used to check for any multicollinearity between all independent variables. The odds of alcohol drinking and drug use were assed using multiple logistic regression and control socio-demographic characteristics.

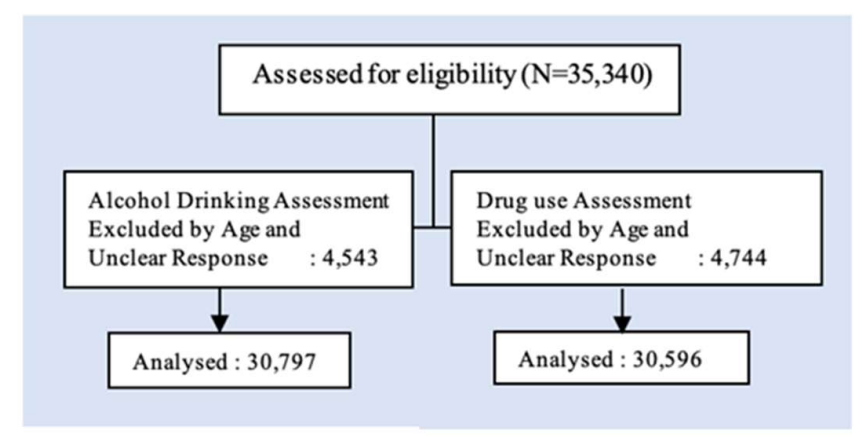

Figure 2. Participant's Flowchart.

In this study, family environment factors as are the parent's marital status, parent's educational background, physical or verbal violence from the parents, low-level parental monitoring and interaction to the students, opportunity to discuss serious problems with 
the parents, and family behaviors. Additional questions are including parent's restriction, level of social bonding and monitoring from parents.

Table 1. Definition of variables.

\begin{tabular}{|c|c|}
\hline Outcome variables & Definitions and Measurement \\
\hline Alcohol drinking & $\begin{array}{l}\text { Self-reported drinking episodes of various alcoholic beverages more than one time in the past } \\
\text { year. Eight various multiple alcoholic beverages were asked to the respondents. All response op- } \\
\text { tions were }(0=\mathrm{No}, 1=\text { Yes). The total score calculated, with higher score indicating levels of alco- } \\
\text { hol drinking (Cronbach's a }=0.8)\end{array}$ \\
\hline Drug misuse & $\begin{array}{l}\text { Self-reported use of any psychotropic substances mentioned in the questionnaire. It is also in- } \\
\text { cluded injected drug users who tried more than one time in the past year. A total of } 36 \text { psycho- } \\
\text { tropic substances were asked to the respondents. All response options were }(0=\mathrm{No}, 1=\mathrm{Yes}) \text {. The } \\
\text { total score calculated, with higher score indicating levels of drug use (Cronbach's a = } 0.7)\end{array}$ \\
\hline \multicolumn{2}{|r|}{ ther } \\
\hline Parent's marital status & $\begin{array}{l}\text { Current marital status of a parent at the time of survey time. A discretization was made to create } \\
\text { a binary response, non-marital status (single, divorced), married, or living together. }\end{array}$ \\
\hline Parent's education & The highest education level attained by father and mother. \\
\hline Experience verbal violence & $\begin{array}{l}\text { Ever experiences one of this violence from parents (likert scales: never, yes rarely, yes often, yes } \\
\text { very often), including } \\
\text { - } \quad \text { cursed with dirty words } \\
\text { - } \quad \text { underestimating student's abilities } \\
\text { - } \quad \text { being insulted } \\
\text { these questions were categorized into binary ( } \mathrm{No}=\text { never experienced all the type of violence, } \\
\text { Yes= ever at least one of the type of violence) }\end{array}$ \\
\hline Experience physical violence & $\begin{array}{l}\text { Ever experiences one of this violence from parents (likert scales: never, yes rarely, yes often, yes } \\
\text { very often), including } \\
-\quad \text { slapped/punched/kicked/hit } \\
-\quad \text { punished by not giving food } \\
-\quad \text { hit by a belt or other rough objects } \\
\text { - } \quad \text { being enslaved for money } \\
\text { these questions were categorized into binary }(\mathrm{No}=\text { never experienced all the type of violence, } \\
\text { Yes= ever at least one of the type of violence) }\end{array}$ \\
\hline Restriction & $\begin{array}{l}\text { Answer one of these conditions (likert scales: never, yes rarely, yes often, yes very often) } \\
-\quad \text { give many rules } \\
-\quad \text { revoke the right to play games or mobile phones } \\
\text { - } \quad \text { did not allow for hanging out or going somewhere for the certain time } \\
\text { these questions were categorized into binary ( } \mathrm{No}=\text { never experienced any restriction, Yes= experi- } \\
\text { enced at least one of restriction) }\end{array}$ \\
\hline Low monitoring & $\begin{array}{l}\text { Answer one of these conditions (likert scales: never, yes rarely, yes often, yes very often) } \\
\text { - } \quad \text { parents never call or being anxious if I get home late } \\
\text { - } \quad \text { parents didn't care wherever and whenever I would go } \\
\text { - } \quad \text { parents never asked about who my close friends are } \\
\text { these questions were categorized into binary ( } \mathrm{No}=\text { never experienced low monitor from parents, } \\
\text { Yes= experienced at least one of the condition) }\end{array}$ \\
\hline Low bonding & $\begin{array}{l}\text { Answer one of these conditions (likert scales: never, yes rarely, yes often, yes very often) } \\
\text { - } \quad \text { family never gives warmth and attention } \\
\text { - } \\
\text { - } \\
\text { families never share stories and experiences } \\
\text { these questions were categorized into binary ( } \mathrm{No}=\text { never experienced that conditions, Yes= expe- } \\
\text { rienced at least one of the condition) }\end{array}$ \\
\hline Discuss serious problems & $\begin{array}{l}\text { Whether the students usually talked about their personal problems with parents; answers were } \\
\text { grouped into two major possibilities: dialogue (yes) and absence of dialogue (never). }\end{array}$ \\
\hline Family risky behavior & $\begin{array}{l}\text { If there were at least one of their family including father, mother, siblings or closed-relative who } \\
\text { consumed alcohol or used drug within past year. }\end{array}$ \\
\hline
\end{tabular}

\section{Results}




\subsection{Socio-demography characteristics}

Among this analyzed population, there was a total of $13.7 \%$ of students $(n=30,797)$ identified as alcohol drinkers while $2.1 \%(n=30,596)$ drug users in the past year. Among students who drink alcohol, $11 \%$ of those were also drug users. Table 2 presents characteristics of socio-demographic both alcohol and drug users. The majority were male and age between 19 to 25 . Among alcohol drinkers, they were more likely academy or university students and living outside Java-Bali, while drug use more likely senior high school students and living in Java-Bali.

Table 2. Socio-demographic characteristics by alcohol drinking and drug use among Indonesian students.

\begin{tabular}{|c|c|c|c|c|c|}
\hline \multicolumn{2}{|c|}{ Socio-demographic } & \multicolumn{2}{|c|}{$\begin{array}{l}\text { Alcohol Drinking } \\
(n=4221)\end{array}$} & \multicolumn{2}{|c|}{$\begin{array}{c}\text { Drug Misuse } \\
(n=619)\end{array}$} \\
\hline & & $\mathrm{N}$ & $\%$ & $\mathrm{~N}$ & $\%$ \\
\hline \multirow{2}{*}{ Sex } & Female & 764 & 18.2 & 104 & 16.8 \\
\hline & Male & 3457 & 81.9 & 515 & 83.2 \\
\hline \multirow{2}{*}{ Age } & $12-18$ & 1923 & 45.6 & 340 & 54.9 \\
\hline & $19-25$ & 2298 & 54.4 & 279 & 45.1 \\
\hline \multirow{3}{*}{ Current education } & Junior high school & 667 & 15.8 & 141 & 22.8 \\
\hline & Senior high school & 1648 & 39.0 & 276 & 44.6 \\
\hline & College/University & 1906 & 45.2 & 202 & 32.6 \\
\hline \multirow{2}{*}{ Region } & Java-Bali & 1392 & 33.0 & 238 & 38.4 \\
\hline & Outside Java-Bali & 2829 & 67.0 & 381 & 61.6 \\
\hline
\end{tabular}

3.2. Demographic Background and Family Environment Factors in relation with alcohol and drug misuse

Table 3 elaborates on the demographic background and family family environment factors concerning alcohol drinking and drug use. Most of the students who drink alcohol and use drugs were living with both parents. Comparing the percentage for every positive case per total respondents, students who live with highly educated parents, low monitoring and bonding, and absence of communication regarding serious problems between the children and the parents, demonstrated a higher percentage of alcohol drinking, as well as drug use. Furthermore, students who experienced verbal and physical violence and possessed a family member who engaged with alcohol drinking and drug use showed a higher percentage of alcohol drinking and drug use. A less-restricted family shows a higher percentage of these behaviors compare to a strict family.

Table 3. Demographic Background and Family Environment Factors in relation with alcohol and drug misuse among students in Indonesia.

\begin{tabular}{|c|c|c|c|c|}
\hline \multirow{2}{*}{$\begin{array}{c}\text { Demographic Background and Family Envi- } \\
\text { ronment Factors }\end{array}$} & \multicolumn{2}{|c|}{$\begin{array}{l}\text { Alcohol Drinking } \\
(n=4221)\end{array}$} & \multicolumn{2}{|c|}{$\begin{array}{c}\text { Drug Misuse } \\
(n=619)\end{array}$} \\
\hline & $\mathbf{N}$ & $\%$ & $\mathbf{N}$ & $\%$ \\
\hline \multicolumn{5}{|l|}{ Parent's marital status } \\
\hline Married/Living together & 3752 & 88.9 & 523 & 84.5 \\
\hline In non-marital status & 444 & 10.5 & 92 & 14.9 \\
\hline \multicolumn{5}{|l|}{ Parent's education } \\
\hline Junior highschool graduates or lower & 1359 & 32.2 & 193 & 31.2 \\
\hline Senior Highschool Graduates & 1595 & 37.8 & 257 & 41.5 \\
\hline College/University graduate & 1146 & 27.1 & 146 & 23.6 \\
\hline \multicolumn{5}{|l|}{ Ever experience verbal violence } \\
\hline No & 2492 & 59.0 & 332 & 53.6 \\
\hline Yes & 1729 & 41.0 & 287 & 46.4 \\
\hline \multicolumn{5}{|l|}{ Ever experience physical violence } \\
\hline No & 2596 & 61.5 & 338 & 54.6 \\
\hline Yes & 1625 & 38.5 & 281 & 45.4 \\
\hline \multicolumn{5}{|l|}{ Restriction } \\
\hline No & 1646 & 39.0 & 233 & 37.6 \\
\hline Yes & 2575 & 61.0 & 386 & 62.4 \\
\hline Low monitoring & & & & \\
\hline
\end{tabular}




\begin{tabular}{ccccc}
\hline No & 2977 & 70.5 & 435 & 70.3 \\
\hline Yes & 1244 & 29.5 & 184 & 29.7 \\
\hline Low bonding & & & & \\
\hline No & 3517 & 83.3 & 502 & 81.1 \\
\hline Yes & 646 & 15.3 & 105 & 17.0 \\
\hline Yes & & & & \\
\hline Never & 2415 & 57.2 & 315 & 50.9 \\
\hline Family risky behaviour & 1769 & 41.9 & 296 & 47.8 \\
\hline No & & & & \\
\hline Yes & 1503 & 35.6 & 228 & 36.8 \\
\hline
\end{tabular}

\subsection{Risk factors of alcohol drinking and drug misuse}

The odds of alcohol and drug use were calculated using multiple logistic regression statistical models shown in Table 4. After adjusting for the effects of the potential confounding socio-demographic covariates in statistical models (age, gender, education) and having risky behaviors friends, there was a shred of strong evidence that some family environment problems increased the tendency of alcohol drinking and drug use among students in Indonesia.

There were six family environment and demographic factors that were highly associated with alcohol drinking among students. Highly educated parents, students who have experienced verbal and physical violence, exposed with a low bonding, never discussed serious problems with parents, and have a family member who engaged in alcohol drinking or drug use have a major influence on students' drinking behavior. The strongest risk factor is a family member who engaged with risky behavior( $\mathrm{AOR}=4.78 ; 95 \% \mathrm{CI}=4.27$ -5.37), followed by students who have never had discussions with parents (AOR $=1.51$; $95 \% \mathrm{CI}=1.34-1.69)$ and have experienced physical violence from parents $(\mathrm{AOR}=1.42 ; 95 \%$ $\mathrm{CI}=1.25-1.61)$.

In general, the family environment patterns are almost the same as seen in drug use students. Parent's marital status, parental restriction, low monitoring, and low bonding are not directly related to drug use behavior. Similar to the behavior of drinking alcohol, the influence of risky family behavior has a strong tendency to drug use behavior in students $(\mathrm{AOR}=2.32 ; 95 \% \mathrm{CI}=1.79-3.01)$.

Table 4. The adjusted odds ratio of family background characteristics by alcohol and drug misuse among students in Indonesia.

\begin{tabular}{|c|c|c|c|c|c|c|}
\hline & \multicolumn{3}{|c|}{ Alcohol use } & \multicolumn{3}{|c|}{ Drug miuse } \\
\hline & AOR & \multicolumn{2}{|c|}{$95 \% \mathrm{CI}$} & \multirow{2}{*}{ AOR } & \multicolumn{2}{|c|}{$95 \% \mathrm{CI}$} \\
\hline & & & & & & \\
\hline Married/Living together & 1.000 & - & - & 1.000 & - & - \\
\hline In non-marital status & 1.122 & 0.938 & 1.341 & $1.597^{*}$ & 1.116 & 2.285 \\
\hline Parent's education & & & & & & \\
\hline Junior highschool graduates or lower & 1.000 & - & - & 1.000 & - & - \\
\hline Senior Highschool Graduates & 0.943 & 0.829 & 1.074 & 1.057 & 0.784 & 1.424 \\
\hline $\begin{array}{l}\text { College/University graduate } \\
\text { Experience verbal violence }\end{array}$ & $1.245^{*}$ & 1.083 & 1.431 & 0.979 & 0.697 & 1.376 \\
\hline No & 1.000 & - & - & 1.000 & & \\
\hline Yes & $1.201^{*}$ & 1.057 & 1.362 & $1.333^{*}$ & 1.098 & 1.803 \\
\hline Experience physical violence & & & & & & \\
\hline No & 1.000 & - & - & 1.000 & - & - \\
\hline Yes & $1.418^{*}$ & 1.252 & 1.607 & $1.556^{*}$ & 1.169 & 2.074 \\
\hline Restriction from parent & & & & & & \\
\hline No & 1.000 & - & - & 1.000 & & \\
\hline
\end{tabular}




\begin{tabular}{|c|c|c|c|c|c|c|}
\hline Yes & 0.878 & 0.758 & 1.017 & 0.901 & 0.629 & 1.289 \\
\hline \multicolumn{7}{|c|}{ Low monitoring } \\
\hline No & 1.000 & - & - & 1.000 & - & - \\
\hline Yes & $1.237^{*}$ & 1.047 & 1.461 & 1.162 & 0.794 & 1.702 \\
\hline \multicolumn{7}{|c|}{ Low bonding } \\
\hline No & 1.000 & - & - & 1.000 & - & - \\
\hline Yes & $1.362^{*}$ & 1.144 & 1.622 & 1.295 & 0.915 & 1.832 \\
\hline \multicolumn{7}{|c|}{ Discuss serious problems } \\
\hline Yes & 1.000 & - & - & 1.000 & - & - \\
\hline Never & $1.511 *$ & 1.347 & 1.695 & $1.811^{*}$ & 1.399 & 2.344 \\
\hline \multicolumn{7}{|c|}{ Family risky behavior } \\
\hline No & 1.000 & - & - & 1.000 & - & - \\
\hline Yes & $4.784^{*}$ & 4.266 & 5.366 & $2.321^{*}$ & 1.793 & 3.001 \\
\hline
\end{tabular}

\section{Discussion}

This study reveals the prevalence of students who ever drink alcohol and are involved in drug use. A 2016 data shows that the prevalence of alcohol drinking among this group was $13,7 \%$, whereas $2,1 \%$ of students were involved in drug use. Looking at the trend from the previous surveys (2006, 2009, and 2011), this indicates a consistent decrease of prevalence of these risky behaviors, which is linear to the target of the United Nations Office on Drugs and Crime Country Program 2017-2020 Indonesia to continue to reduce the number of drug abuse [8]. Based on the 2015-2019 RPJMN, the government has set a target to reduce drug abuse prevalence by $0.05 \%$ every year [20].

Several studies have been conducted to see the relationship between background characteristics in the family environment with alcohol and drug misuse. The study findings are consistent with the prior literature demonstrating a significant risk effect of family environmental factors with students' risky behavior. Experiences of verbal and physical violence, never discussing serious problems, and risky family behavior are associated with alcohol drinking and substance use. Students who have experienced verbal and physical violence from their parents have a higher tendency to consume alcohol and drug use [21]. Adolescents who experience violence will likely suffer from stress and consume alcohol as self-medication [22].

Furthermore, there is a prior belief that using drug or substance is beneficial as a maladaptive strategy to help regulate emotional states and cope with stress or disruptive interpersonal violence emotions $[21,23,24]$. In recent years, violence has been considered a much broader problem that involves the family, community and public health [25]. Experiencing violence at home plays pivotal roles in enhancing people to be engaged in alcohol drinking and drug use [14,21]. In parenting, the family environment has a major influence on a child's development, therefore a deep understanding of how violence occurs in a family and its subsequent impact on the child should be emphasized. As the results of physical violence and witnessing domestic violence in the family, stress and trauma have a strong negative impact on a child neurodevelopmental that may lead to early initiation of alcohol drinking and drug use [14,21].

Having parents who are too restrictive in allowing children to do their preferred activities, in the form of exaggerating rules such as playing games, and forbidding children to leave home for a certain period is not related to the child's behavior in consuming alcohol and using drugs. Children who obey their parents' rules tend to express good behavior and enhance refusal skills to negative persuasion [26]. Low monitoring, illustrated by the lack of anxiety and never worrying if their children come home late at night, never reprimands where the child goes and never asks who their close friends are, has an association to alcohol consumption but does not look strong in substance use, similar with low bonding factor. Several studies state that how families influence the use of hard liquor and illicit drug use is directly through their risk behavior and not through conventional bonding (indirect factor) [11]. Frequent conflict in a family can be emotionally draining and reduce the parent's ability to recognize and respond to their children's emotional 
needs [27]. Parent-child conflict is moderately associated with decreased warmth and support in parents, reduced behavioral control and monitoring and more verbal criticism and physical punishment [28], impairments in parent-child relationships [29], and relatively higher parental psychological control and decreased parental monitoring [30,31]. However, several studies also stated that lack of parental bonding was associate with illicit drug use $[32,33]$. Whereas parental supervision and connectedness were protective factors for substance use [34].

The closeness of children with parents is portrayed by how frequently they discuss serious matters with children. On this occasion, parents play a key role in transmitting attitudes, values, and beliefs about lifestyles and that values can stimulate positive outcomes in the cultural and school domains of their children [35]. Children who do not get along with their parents tend to rely on their friends as a source of information, which sometimes provides unreliable information. It is also harmful to children if they are surrounded by some friends that engaged in negative activities. Family environment and experiences, either positive and negative, affect children's social, emotional, and psychological well-being. Furthermore, conflict in a family that leads to poor communication creates less effective monitoring efforts of adolescents' risky behavior [36]. The distant relationship between parents and children can initiate alcohol use, particularly in early adolescence [14]. Consistent involvement in family life and clear roles, as well as a presence of affection, can form a stronger personality and reluctant to get involved in negative things [11]. However, there is a notable assumption that the quality of family life plays essential roles in alcohol drinking behavior, not the structure of the family itself, whether the children live with an unmarried or single parents or living with a complete parent [14].

A family approach prevention model was accommodated by a Healthy Indonesia Program launched by the Indonesia Ministry of Health in 2016 [37,38]. Unfortunately, very limited efforts on the prevention of smoking, alcohol drinking, and drug use in adolescents were mentioned. Indonesia National Narcotics Board mainly focused on arresting drug dealers and users in Indonesia, and it is still a controversy whether these drug users should be treated as a victim or a person committed to crime. Besides, alcohol drinking and drug abuse are still not on the top priority, hence, an increasing trend of these cases is inevitable.

It is clear that having a family member, either father, mother, or sibling whoever consumed alcohol or drugs has a strong impact on children's behavior. There is evidence in the biopsychosocial research that various influences of the family environment including having a parent who drinks alcohol and earlier exposure to familial alcohol drinking put children at greater risk for drug use and other related problems than children who were not exposed. Adolescents who have parents or siblings who drink alcohol or use drug tend to initiate similar risky behavior [39]. Children will always cope with the behavior of those closest to them and make them as a role model. The alcohol drinking and school problem behavior connection involves exposure and vulnerability to a parental drinking problem [12].

Several limitations of the study should be noted. First, this study presented a crosssectional design that could not see causality. We were not able to detect which conditions precede the occurrence of the event. For example, it remains unclear whether certain negative life events, such as exposure to violence, contributed to drug use, or whether their illicit drug involvement was the cause of the experience of violence. A longitudinal design is needed to address this shortcoming. Second, the data obtained tend to be underreported because the topic related behaviors in the survey is still taboo in Indonesia. Self-presentation issues may predispose adolescents to either exaggerate or minimize their risk taking behaviors [40]. Third, the survey only covers BNN areas program and some areas with a fairly high prevalence of drug use, so the finding must be carefully interpreted. Although students from a wide range of schools were included, the participants were restricted to students attending schools at that time of survey. Therefore, the findings may not generalize to out-of-school adolescents. 


\section{Conclusions}

This study addressed the family factors and their impact on the behavior of the children. Parental support and monitoring have been shown to reduce the prevalence of adolescent drug use in many studies. But this does not apply if many conflicts happen between parents and children. The form of monitoring will be very different and varied. These findings have implications for preventive interventions to strengthen parental support, control and parenting style with less conflict. Results affirm the importance of tending to parent-child communication and relations in the process of ameliorating interactions. Parenting style is an essential interpersonal factor. As such, this study's results should be informative for parents, family practitioners, educators, and social policy planners. The program is not limited to prevention but the intervention effort for those who have experienced poor family circumstances with associated substance use. This might maximizing the role of adolescent care center in each primary health care in subdistrict level to develop program such as training family members in conflict resolution and maximizing the adolescents in youth-orientated community activities. Future research might investigate the relations between family characteristics and alcohol and drugs by using a longitudinal study to assess a broader range of information.

\section{Patents}

This section is not mandatory but may be added if there are patents resulting from the work reported in this manuscript.

Author Contributions: All authors equally contributed to the manuscript. Conceptualization: NAR. Data curation: NAR, BU, PKS. Formal analysis: NAR, MN. Methodology: BU. Writing original: NAR. Writing review \& editing: BU, PKS.

Funding: This research was funded by University of Indonesia through International Research Collaboration Grant 2019.

Institutional Review Board Statement: As the study entailed analysis of secondary data containing no personally identifying information, an exempted review was granted from the Faculty of Public Health Research Ethics Committee. Ethical clearance was issued in 2014 by the Ethical Committee for Public Health Research of the Faculty of Public Health (IRB \#00006120) at Universitas Indonesia, after reviewing all study procedures.

Informed Consent Statement: Not applicable.

Data Availability Statement: The data available on request to the corresponding author.

Acknowledgments: The authors acknowledge the Indonesia National Narcotics Board staff and the Centre of Health Research, University of Indonesia.

Conflicts of Interest: The authors declared no potential conflicts of interest with respect to research, authorship, and/or publication of this article.

\section{References}

[1] BKKBN. Policy Brief Kajian Profil Penduduk Remaja (10-24 Tahun): Ada Apa dengan Remaja? Jakarta: 2011.

[2] Romadlona NA. Partner Discussion and Adolescent Health Risk Behaviors in Indonesia: Indonesia Demographic and Health Survey 2012. University of Indonesia, 2016.

[3] Ellickson PL, Mcguigan KA, Adams V, Bell RM, Hays RD. Teenage Alcohol Misuse: A Big Problem and a Different Solution. Rand Drug Policy Res Cent 1998:1-2.

[4] Cox J, Sagor R. At Risk Students: Reaching and Teaching Them by Jonas Cox, Richard Sagor / Kissly: Affordable Ebooks. 2nd ed. Larchmont, New York: Routledge; 2004.

[5] BPS, BKKBN, Kemenkes, ICF. Indonesia Demographic and Health Survey 2012. Jakarta: 2013.

[6] Supit A, Mamuaja P, Pissu A. Alcohol consumption among college students in Minahasa, Indonesia: a cross-sectional study towards the formulation of intervention strategies. Int J Community Med Public Heal Supit A Al Int J Community Med 
Public Heal 2017;4:4630-7. https://doi.org/10.18203/2394-6040.ijcmph20175342.

[7] Huggins R. United Nations Office on Drugs and Crime. Encycl Drug Policy 2012. https://doi.org/10.4135/9781412976961.n354.

[8] UNODC. Country Programme 2017-2020 Indonesia “Making Indonesia safer from crime, drugs and terrorism." Jakarta: 2017.

[9] BNN P. Penggunaan Narkotika di Kalangan Remaja Meningkat n.d. https://bnn.go.id/penggunaan-narkotika-kalanganremaja-meningkat/ (accessed August 19, 2021).

[10] Bahr SJ, Maughan SL, Marcos AC, Li B. Family, Religiosity, and the Risk of Adolescent Drug Use. J Marriage Fam 1998;60:979. https://doi.org/10.2307/353639.

[11] Fraser M. Family, School, and Peer Correlates of Adolescent Drug Abuse. Soc Serv Rev 1984;58:434-47. https://doi.org/10.1086/644217.

[12] Jennison KM. The impact of parental alcohol misuse and family environment on young people's alcohol use and behavioral problems in secondary schools. J Subst Use 2014;19:206-12. https://doi.org/10.3109/14659891.2013.775607.

[13] Ellis DA, Zucker RA, Fitzgerald HE. The role of family influences in development and risk. Alcohol Health Res World $1997 ; 21: 218-26$.

[14] Carvalho V, Pinsky I, Silva RADSE, Carlini-Cotrim B. Drug and alcohol use and family characteristics: a study among Brazilian high-school students. Addiction 1995;90:65-72. https://doi.org/10.1046/j.1360-0443.1995.9016510.x.

[15] Espelage DL, Hong JS, Valido A. Associations Among Family Violence, Bullying, Sexual Harassment, and Teen Dating Violence. Adolesc Dating Violence 2018:85-102.

[16] Ehrensaft MK. Intimate partner violence: Persistence of myths and implications for intervention. Child Youth Serv Rev 2008;30:276-86. https://doi.org/10.1016/j.childyouth.2007.10.005.

[17] UNODC. Conducting School Surveys on Drug Abuse Global Assessment Programme on Drug Abuse (GAP) Conducting School Surveys on Drug Abuse 2013.

[18] UNODC. Final Independent project evaluation of the“Promoting Alternatives to Incarceration for Convicted Drug Users, including Rehabilitation and Probation" (Forming part of the Sub-Programme 5 on Drugs and HIV of the Indonesia Country Programme 2012-2016). New York: 2017.

[19] Powers DA, Xie Y. Statistical Methods for Categorical Data Analysis: 2nd Edition. Second Edi. Bingley, UK: Emerald Group; 2008.

[20] Kementerian Kesehatan. Infodatin Pusat Data dan Informasi Kementrian Kesehatan 2017: Narkoba. Jakarta: 2017.

[21] Yi S, Poudel KC, Yasuoka J, Palmer PH, Yi S, Jimba M. Risk vs. protective factors for substance use among adolescents in Cambodia. J Subst Use 2011;16:14-26. https://doi.org/10.3109/14659890903531261.

[22] Peleg-Oren N, Cardenas GA, Comerford M, Galea S. Exploratory study on the association between interpersonal violence experiences and alcohol use among adolescents. Soc Work Res 2013;37:277-85. https://doi.org/10.1093/swr/svt016.

[23] Kilpatrick DG, Acierno R, Saunders B, Resnick HS, Best CL, Schnurr PP. Risk factors for adolescent substance abuse and dependence: Data from a national sample. J Consult Clin Psychol 2000;68:19-30. https://doi.org/10.1037/0022-006X.68.1.19.

[24] Dube SR, Miller JW, Brown DW, Giles WH, Felitti VJ, Dong M, et al. Adverse childhood experiences and the association with ever using alcohol and initiating alcohol use during adolescence. J Adolesc Heal 2006;38:444.e1-444.e10. https://doi.org/10.1016/j.jadohealth.2005.06.006.

[25] James J, Pamela M. Epidemiology of alcohol-related violence. Alcohol Health Res World 1993;17:93.

[26] Guo J, Hawkins JD, Hill KG, Abbott RD. Childhood and adolescent predictors of alcohol abuse and dependence in young adulthood. J Stud Alcohol 2001;62:754-62. https://doi.org/10.15288/jsa.2001.62.754.

[27] Fincham FD. Understanding the Association Between Marital Conflict and Child Adjustment: Overview. J Fam Psychol 1994;8:123-7. https://doi.org/10.1037/0893-3200.8.2.123.

[28] Krishnakumar A, Buehler C. Interparental Conflict and Parenting Behaviors: A Meta-Analytic Review. Fam Relat 2000;49:2544. https://doi.org/10.1111/j.1741-3729.2000.00025.x. 
[29] Erel O, Burman B. Interrelatedness of marital relations and parent-child relations: A meta-analytic review. Psychol Bull 1995;118:108-32. https://doi.org/10.1037/0033-2909.118.1.108.

[30] Bradford K, Vaughn LB, Barber BK. When there is conflict: Interparental conflict, parent-child conflict, and youth problem behaviors. J Fam Issues 2008;29:780-805. https://doi.org/10.1177/0192513X07308043.

[31] Stone G, Buehler C, Barber BK. Interparental conflict, parental psychological control, and youth problem behavior. Intrusive Parent. How Psychol. Control Affect. Child. Adolesc., American Psychological Association; 2004, p. 53-95. https://doi.org/10.1037/10422-003.

[32] El Kazdouh H, El-Ammari A, Bouftini S, El Fakir S, El Achhab Y. Potential risk and protective factors of substance use among school adolescents in Morocco: A cross-sectional study. J Subst Use 2019;24:176-83. https://doi.org/10.1080/14659891.2018.1535003.

[33] Alwan H, Viswanathan B, Rousson V, Paccaud F, Bovet P. Association between substance use and psychosocial characteristics among adolescents of the Seychelles. BMC Pediatr 2011;11:85. https://doi.org/10.1186/1471-2431-11-85.

[34] Peltzer K. Prevalence and correlates of substance use among school children in six African countries. Int J Psychol 2009;44:378-86. https://doi.org/10.1080/00207590802511742.

[35] Clark TT, Nguyen AB. Family factors and mediators of substance use among African American adolescents. J Drug Issues 2012;42:358-72. https://doi.org/10.1177/0022042612461770.

[36] Kliewer W, Murrelle L. Risk and Protective Factors for Adolescent Substance Use: Findings from a Study in Selected Central American Countries. J Adolesc Heal 2007;40:448-55. https://doi.org/10.1016/j.jadohealth.2006.11.148.

[37] Kementerian Kesehatan. Warta Kesmas: Keluarga Sehat Wujudkan Indonesia Sehat. Ed 03 2017:5-48.

[38] Program Indonesia Sehat dengan Pendekatan Keluarga - PISPK n.d. http://pispk.kemkes.go.id/id/programpispk/pelaksanaan-pendekatan-keluarga-sehat/ (accessed August 19, 2021).

[39] Samek DR, Keyes MA, Hicks BM, Bailey J, McGue M, Iacono WG. General and specific predictors of nicotine and alcohol dependence in early adulthood: genetic and environmental influences. J Stud Alcohol Drugs 2014;75:623-34. https://doi.org/10.15288/jsad.2014.75.623.

[40] Le TN, Kato T. The role of peer, parent, and culture in risky sexual behavior for Cambodian and Lao/Mien adolescents. J Adolesc Heal 2006;38:288-96. https://doi.org/10.1016/J.JADOHEALTH.2004.12.005. 